\title{
Institutional factors in subsidiaries' technology strategies
}

\author{
Paulo Tromboni de Souza Nascimento, Lydia Lopes Correia da Silva, \\ Francisco Carlos Tadeu Starke-Rodrigues, Abraham Sin Oih Yu \\ Universidade de São Paulo \\ e-mails: tromboni@usp.br; lydia_lopes@ig.com.br; franciscostarke@starconsult.com.br; abraiyu@ipt.br
}

\begin{abstract}
How subsidiaries arrive at technological strategies that may become emergent at the global level? Fossil fuel cars dominate the world markets. Now, flex fuel cars are the Brazilian local dominant design. Clearly, subsidiaries made differing choices in market entry timing and engine compression ratios. Why did the main Brazilian auto industry subsidiaries get deeply involved with flexible fuel cars? How did they arrive at their current technology strategies? To explain their strategies, one must consider Brazil's local institutional factors a large and fast growing local market, the long sugar cane history, government incentives, the subsidiaries' relevance to their headquarters, their early involvement in the development of ethanol-fueled vehicles, and the subsidiaries' differing R\&D autonomies.
\end{abstract}

Keywords: biofuel strategy, subsidiaries autonomy, subsidiaries innovation role, subsidiary's capabilities, renewable fuel cars.

\section{Introduction}

Oil still account for $97 \%$ of all fuel consumed worldwide by auto engines (NIGRO; SZWARC, 2008). In contrast, Brazil has long been betting on biofuels. Currently, there is steady growth in renewable fuels and they already account for $18 \%$ of the transportation sector energy use (AGÊNCIA..., 2011).

In 2003, flexible fuel (flex fuel) technology, which allows vehicles to run on gasoline, ethanol, or any mix thereof, was launched in Brazil. Today, around $90 \%$ of the Brazilian yearly sales and almost half of the country's light vehicles fleet are flex-fuel vehicles (MARQUES, 2011). Brazilians seem to be satisfied with this friendly model of choosing fuel type at the gas station. Prior to the flex fuel wide spread use, cars were only available either for ethanol or gasohol (mixture of 20 to $25 \%$ ethanol and gasoline), and buyers had to make this choice when purchasing the vehicle. Ethanol consumption has since been rapidly increasing. Today it roughly accounts for half the Brazilian cars fuel consumption.

There are no Brazilian-owned car companies. They are all subsidiaries. This combination of leadership in biofuels and lack of a true national auto industry begs for an explanation. Few studies thus far have been able to show how and why, over time, Brazilian subsidiaries have shifted their strategic positions, often in the opposite direction from their headquarters.

This study seeks to understand how local subsidiaries arrived at their present strategic flex-fuel technology positions. Over time, strategic initiatives arose in response to the Brazilian automotive sector context. We have thus framed our research problem as uncovering the strategies shown in the flex-fuel segment and the factors that determine their adoption by each automaker.

\section{Local institutional factors in emergent strategies}

Kogut and Zander (1993, p. 625) define a multinational as "[...] an economic organization that evolves from its national origins to spanning across borders." A large multinational enterprise will feature corporate strategies, division strategies, business unit strategies, functional strategies and project strategies at various levels, all of which coexist in a complex tangle, not always co aligned, as the circumstances that condition these strategies are widely different.

Ansoff (1988) is the main precursor of the idea of strategy as a rational, deliberate, plan of action meant to deal with the corporate environment. Strategy in this sense is an explicit guide to a desired pattern (ANDREWS, 1991) of decisions and actions by the company.

Global Companies are tempted to promote maximum action coherence, but this entails the risk of poorly responding to local circumstances. Business units will thus often follow a bottom-up model, creating new options not entirely consistent with general management strategic intents and thrust (BOWER; DOZ; GILBERT, 2005).

Mintzberg $(1978,1991)$ stress that a strategy may be an observed pattern in an action sequence. Thus conceived, strategy is a descriptive term of the company observed behavior. This concept gives rise to the intriguing possibility of observing behavior that reveals a pattern without a prior intent. An emergent strategy (MINTZBERG, 1991) 
could even go unrecognized by the leaders of a company. It can also be later perceived and explicitly adopted as an organizational strategy.

Noda and Bower (2005) suggest that the investment and divestment process follows a logic of growing commitment as successes gradually build up, which affords great importance to the first few attempts, the precedents. That is, the first results of prospecting activity begin to shape beliefs on what is worth exploiting, and successive attempts tend to confirm these beliefs, providing the corporation with a structural (structure and incentives) and strategic (business focus) context.

Bower, Doz and Gilbert (2005) tells the very interesting story of how GM reacted to the fall of the Berlin Wall with an emergent strategy originating in its local division, which decided to invest in Eastern Europe despite express head office instructions to focus manufacturing on more productive units. What, then, determines local emergent strategies? How do they come about, how are they adopted and legitimized?

For the purposes of the present study, we shall consider as an emergent strategy one that arises in a regional unit in response to local conditions and creates global options for the company as a whole.

Porter (1990) concluded, with his famous diamond, that countries have competitive edges that culminate in global market leadership, due to four interrelated factors: (1) production factors conditions, (2) demand conditions, (3) related and supporting industries, and (4) firm strategy, structure, and rivalry, as well as two exogenous factors: (1) government and (2) chance.

Moon, Rugman and Verbeke (1998) in their study of the Korean and Singapore markets, expand Porter's (1990) original model into the Double Diamond, one global and another at the national level, which takes into account the role of multinationals in a country's economy. To the authors (MOON; RUGMAN; VERBEKE, 1998), Porter's Diamond does not provide an explanation for companies' multinational activities because it advocates that the advantage lie in focusing activities in a single location with the best conditions. Porter's companies are thus solely exporters; his model does not explain the advantages provided by operating in multiple locations.

Unfortunately, although he recognizes the distinction between static and dynamic factors, Porter does not stress institutional aspects on market organization or on the development of demand and production factors. He therefore does not fully capture the dynamic aspect of the competency-building process, which sets the foundation for the creation of distinctive competencies and the possibility of a subsidiary becoming more capable than the head office in a field that is later revealed to be strategic, sometimes even by the initiative of the subsidiaries themselves.
Currently, the need to harmonize global and local activities adds complicating factors to the mix of product development and project portfolio management in large multinational corporations. London and Hart (2004, p. 350) stated "[...] with established markets becoming saturated, multinational corporations (MNCs) have turned increasingly to emerging markets (EMs) in the developing world." Further, in the article, the authors conclude that:

[...] results suggest that the success of initiatives targeting low-income markets is enhanced by recognizing that Western-style patterns of economic development may not occur in these business environments. Business strategies that rely on leveraging the strengths of the existing market environment outperform those that focus on overcoming weaknesses. (LONDON; HART, 2004, p. 350)

So, local institutional factors have an important role on the development of new technology by multinational branches and also may lead to emerging strategies that can become global options for the multinational companies, as can be seen in the twin cases of flexfuel cars and ethanol as fuel in Brazil.

In their case study of the software development for flex-fuel vehicles, Nascimento et al. (2009b) show the importance of institutional factors in fostering the development and large-scale adoption of multi-fuel injection in Brazil. Factors such as the strong presence of sugarcane growers and alcohol producers, the scarcity of oil, the concentration of energy policies in government hands, and the institutionalized characteristics of the Brazilian auto market, among others, played a predominant role in the innovation and adoption of flex-fuel vehicles in Brazil.

\section{Research methodology}

The empirical part of this study was conducted as a research assignment to students of the Business Administration graduate program at the University of São Paulo (USP). Two professors defined subjects, set objectives, guided the students' work, and integrated the research results into a whole.

Part of the data and information was collected in 2008, particularly those concerning the introduction of flex-fuel technology by tier 1 suppliers operating in Brazil - Bosch, Magneti Marelli and Delphi (YU et al., 2009a; NASCIMENTO et al., 2009a). During this first stage, we also interviewed GM and VW experts, which allowed a comparison between the joint automaker/ supplier development strategies adopted by these companies (YU et al., 2009b).

The interviewees contacted in each of the companies and associations occupy executive positions and were actively involved in the development and adoption of flexfuel technology. 
Study groups with at least one professor and one student conducted the interviews from August to December 2009. The interviews focused on automaker representatives regarding their activities and intentions, and secondary data was collected and organized to reveal the different strategies adopted by automakers concerning flex-fuel vehicles and biofuels, as well as the apparent causes of these differences. Secondary data was also used to assess the companies' market positions and engines' compression ratios.

All the major industrial players involved with the introduction of flex fuel technology - Bosch, Magnetti Mareli, Delphi, GM and Volkwagen - were researched. Therefore, the study covers the relevant universe for this research.

\section{Ethanoland flex fuel vehicles in Brazil}

Brazil has a long history of ethanol as a fuel. Up to $15 \%$ (E15), engines require no modifications, and only minor adaptations are needed to reach E25 (AMATUCCI; SPERS, 2009). As early as the 1930s, experiments were made in fueling cars with ethanol (NARDON; ATEN, 2008). There has also been legislation mandating ethanol addition to gasoline from $5 \%$ in the 1930 s up to $25 \%$ today, to provide the gasohol available at fuel station.

In 1978, a protocol was signed between the Brazilian Federal Government and the National Automotive Manufacturers Association - ANFAVEA (ASSOCIAÇÃO..., 2010) - setting up some financial and tax incentives for cars running on ethanol. The Government also made hydrate ethanol (around $5 \%$ water) pumps mandatory for all fuel stations.
The first exclusively ethanol-powered mass-market car model produced in Brazil was the Fiat 147, in 1978. From the 1980s onward, Volkswagen, General Motors, Ford and FIAT have offered car models that run on hydrate ethanol and gasohol, ranging from E20 to E25.

Unfortunately, in the late 1980s, sugar prices rose steeply in international markets, while ethanol prices remained low domestically. This situation led to an ethanol shortage that severely damaged public confidence on ethanol supply. In 21 st century's first decade, relative prices have again made ethanol very competitive with gasoline (GOLDENBERG et al., 2004), as the result of a long productivity improvement curve (MACEDO, 2007).

After the flex fuel arrival, the typical car owner is no longer a hostage to the ethanol or auto producers' economic interests. Now, customers do not have to decide whether they want to buy an ethanol or a gasoline car. This decision can be made at each tank refilling at the fuel station, which allows, on each occasion, the choice for the cheaper option. Whenever and wherever ethanol exceeds 70\% gasohol's price, the costumer may use the latter, or vice versa. This significant flexibility has won most car users over to flexfuel models. In the beginning, the Government also helped with tax incentives for flex fuel vehicles.

Therefore, it is easy to understand Figure 1, which shows wholesales for gasoline, pure-ethanol, and flex-fuel cars. Pure hydrate ethanol cars dominated the late 1980s, followed by a sudden and deep drop since the 1990. At this century opening, flex-fuel cars became dominant in the market.

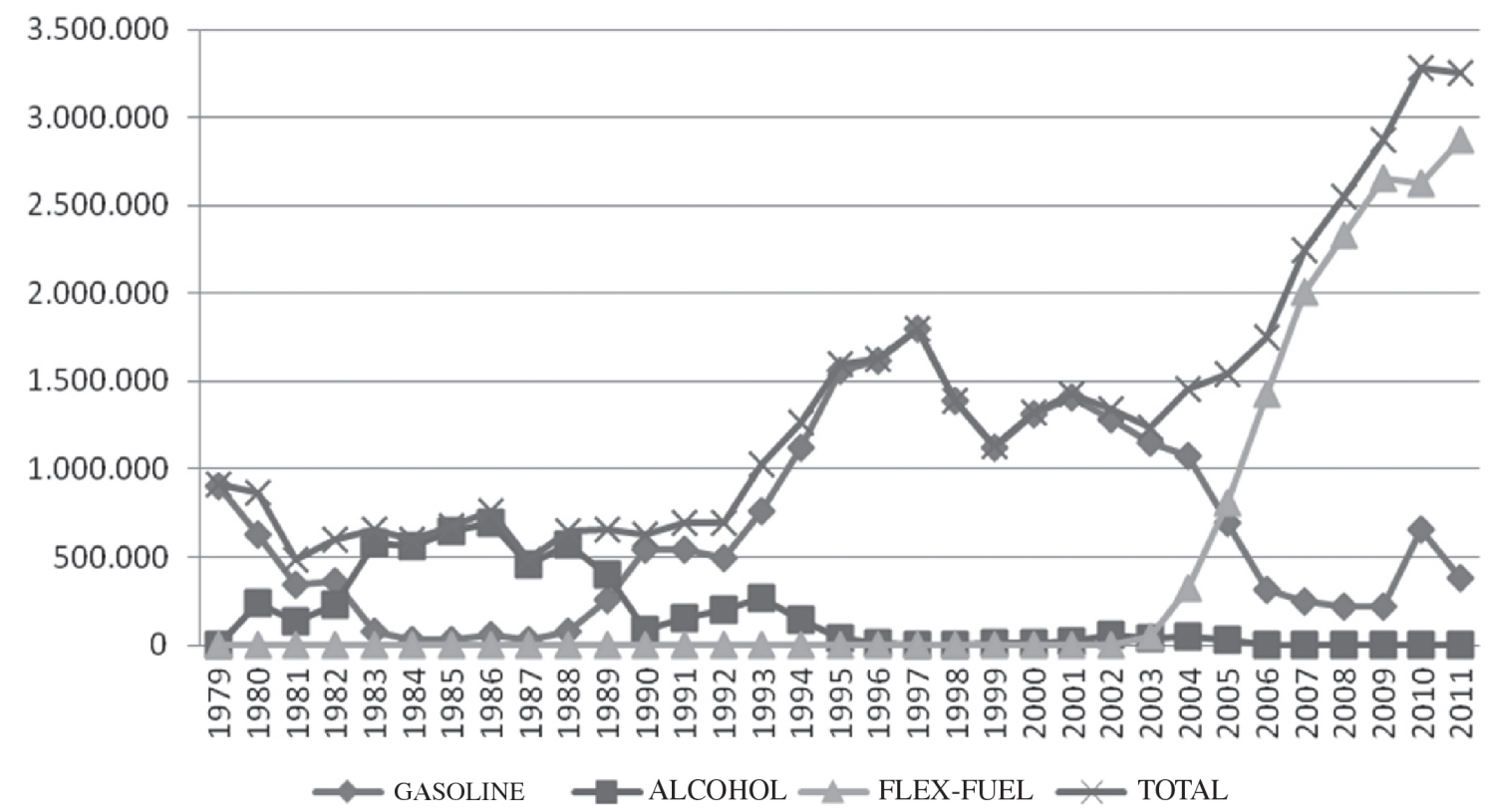

Figure 1. Flexible fuel car architecture dominance in the Brazilian market. Source: Associação Nacional dos Fabricantes de Veículos Automotores (2010). Adapted by the authors. 


\section{Automakers flex-fuel market entry}

Figure 2 shows flex fuel market share data for the main automakers in Brazil since march, 2003, when Volkswagen launched the Gol Total Flex, the country's first mass-produced flex-fuel model. It reached the third spot in auto market share at the time, with a model only about R $\$ 1.500$ (about US\$700,00) more expensive than its gasohol counterpart.

In June 2003, General Motors introduced its new flexfuel Corsa, at the same price as the gasohol model. In October, market leader Fiat launched the new flex-fuel Palio, but only for the 1.3-liter engine version. By the end of that year, eight flex-fuel models were available. In July 2004, Ford introduced the flex-fuel Fiesta to the market. Over the next few years, with differing delays followed the other automakers operating in Brazil. See Figure 3 for these dates.

Market share performance after the launch of each automaker's flex-fuel model may be clearly seen in Figure 3 . Fiat lost briefly its leadership to GM after the flex fuel, but recovered since 2005, closely followed by Volkswagen and GM.

Ford's market share increased for at least two consecutive years - 2005 and 2006 - following the launch of its flex-fuel vehicle, but by 2007 and 2008 had dropped $0.3 \%$ and $0.5 \%$ respectively as compared to 2004. For Honda, Peugeot, and, later on (2007), Toyota, the sales grew in the year following the launch of flex-fuel models: Honda gained $1.1 \%$ share between 2006 and 2008, Peugeot's share grew $0.9 \%$ between 2005 and 2008, and Toyota's increased by $1.3 \%$ between 2007 and 2008.
Renault did not experience any market growth in the year that followed the launch of its flex-fuel model; in fact, its market share dropped $0.7 \%$ between 2004 and 2005 . In 2008, however, Renault reached a record market share, with a $0.7 \%$ increase compared to its 2004 figure of $3.6 \%$. By 2008 , practically all of the major automakers present in Brazil had already launched flex-fuel models. Offering this option to consumers had evidently become an essential means to consolidate an automaker's market share.

\section{Flex fuel engines development}

Flex-fuel technology was preceded by several important innovations that made it possible, including engine technologies and electronic fuel injection for ethanol-fueled cars. Electronic fuel injection completely replaced the electro-mechanical carburetor technology with advanced electronic hardware and software. Electronic fuel injection was developed in the 1970s and has since been improving.

The challenge of flex-fuel injection is to quickly detect and adjust for changes in the gasoline-ethanol ratio. Pefley et al. (1980) is likely among the first scientific studies of mixed gasoline, methanol, and ethanol fuels for commercial engines. The first flex-fuel solutions, developed in the USA, made use of a capacitive sensor that detected this ratio before combustion. But these sensors were too costly for the Brazilian market. The low cost solution was found in post-combustion detection of the gas-ethanol ratio through further use of an oxygen sensor (the lambda probe) already incorporated into the exhaust system for environmental control purposes. Capacitive sensor-free fuel mix detection reduced the total cost of the fuel injection

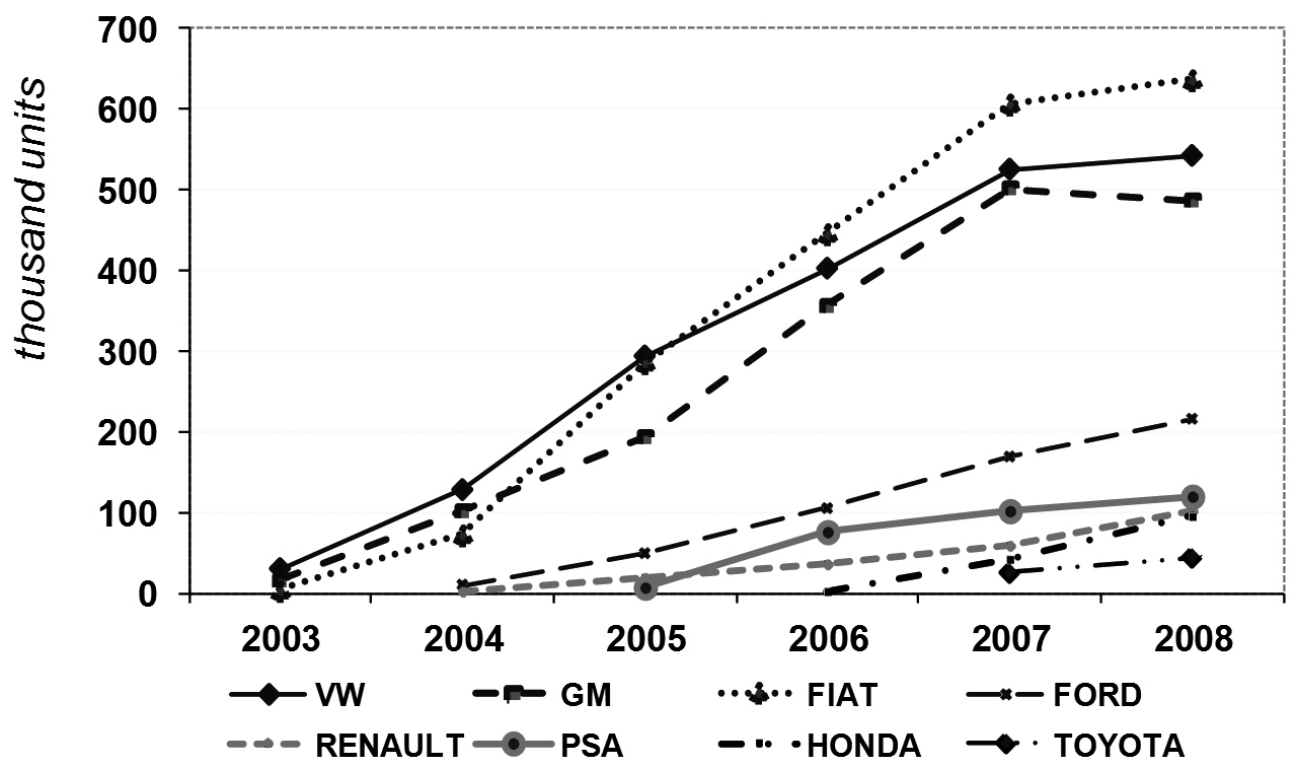

Figure 2. Flex-Fuel Vehicle Launches and Number of Units Sold by Automaker. Source: Associação Nacional dos Fabricantes de Veículos Automotores (2010). 


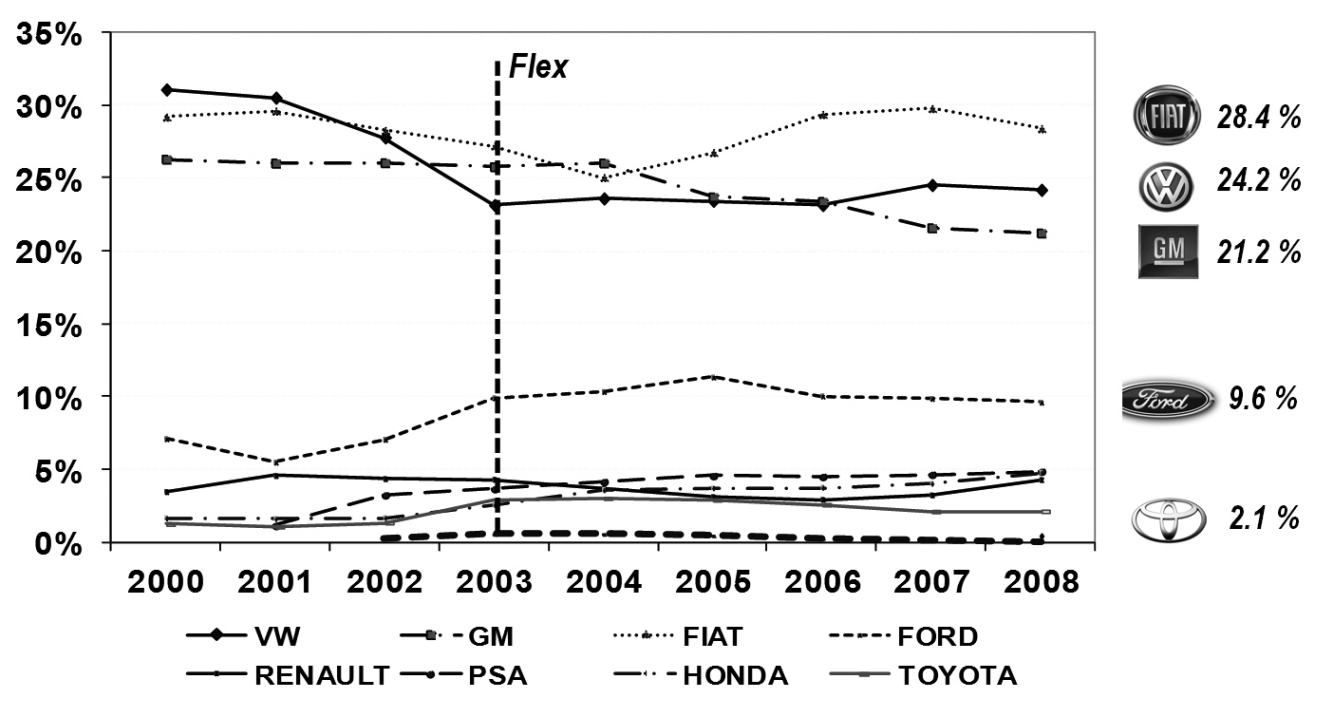

First flex fuel model introduction:

$\begin{array}{lllll}\text {-VW } & \text { March 2003 } & \text { - FORD } & \text { July 2004 } & \text { - HONDA Nov } 2006 \\ \text { - GM } & \text { June 2003 } & \text { •RENAULT Oct 2004 } & \text { - TOYOTA May } 2007 \\ \text { - FIAT } & \text { Oct 2003 } & \text { - PSA } & \text { March 2005 } & \text { - NISSAN Mar 2009 } \\ & & & & \end{array}$

Figura 3. Brazilian Vehicle Market Share - Cars and Lights. Source:Associação Nacional dos Fabricantes de Veículos Automotores (2010). Adapted by the authors.

system, but the software that manages engine variables had to be redeveloped. Flex-fuel management software had around 20\% more lines of code for learning algorithms that adjust engine operation to any usage situation not lab tested. It also requires extensive changes in other major software components. Proprietary control software and competence therefore became one differentiating factor in the competition among flex-fuel injection systems' manufacturers like Bosch, Magneti Mareli and Delta.

In the flex fuel engine development, one very relevant technical decision is the definition of the engine compression ratio. Due to its higher knocking resistance (octane rating), compared to gasoline, the use of ethanol has allowed car manufacturers to design engines with higher compression ratio and therefore to improve performance.

The flex engine designers may adopt conservative values, maintaining the compression ratio of a gasoline engine (range from circa 9:1 to around 10.5:1), thus impairing the ethanol performance, or can opt for an intermediate value (from 10.5:1 to 12:1, approximately). Or even choose the bold option, optimizing the engine operation for ethanol fuel (compression ratio around 13:1), which, to avoid the knocking when using gasoline, requires further development, for example, recalibration of the engine management system or reconfiguration of engine peripheral systems (ignition, intake, cooling, etc.).
Since its inception in 2003, the flex fuel technology has been under constant improvement. The VW subsidiary has introduced successive versions of flex engines, where the compression ratio changed from 10,5:1 (launch) to 13:1 (2009 version) for small flex 1.0 liter engine, among others various modifications (YU et al., 2009a, 2010).

Compression ratios for various flex fuel engines shown in Figure 4. The data is grouped by engine size: 1.0 liter; from 1.3 to 1.6 liter; and from 1.8 to 2.0 liter. In addition, it shows the various technological strategies followed so far by the Brazilian subsidiaries. In subcompact car segments (engines up to 1.6 liter) the incumbents VW, GM and Ford, took the lead in increasing compression ratios, clearly favoring the ethanol operation, with Fiat following closely, adopting intermediate solutions between ethanol and gasoline optimization.

The newcomers have been very conservative, adopting compression ratio values near to gasoline use, except Honda, which seems to be reacting a little faster (engines from 1.8 to 2.0 liters segment).

Though these data do not allow definitive conclusions, the flex engine technological evolution, in general, and the specific option for higher compression ratio, increasingly capturing the benefits of ethanol use, are clear indication of engineering capabilities (experience in ethanol engine 
development, managerial autonomy) and suggest the strategic priorities of Brazilian automakers subsidiaries.

\section{Relative importance of Brazilian automakers in their groups}

Brazil is the seventh-largest world economy. In 2009, it became the fifth-largest manufacturer of automotive vehicles, with 3 million units sold (JATO..., 2009). Whereas the worldwide market showed a $4.2 \%$ drop in car sales, the Brazilian market increased $12.66 \%$ from 2008. The U.S. has a ratio of 1 car for every 1.2 inhabitants, and China, 1 car for every 29 people. Brazil has an intermediate ratio of 1 car for every 7.4 people. According to Barros (2009), in 2008, Brazil showed the largest gain among the world's top 20 sellers, with a $15 \%$ increase in vehicle registration from 2007.

In 1993, the government reduced the Industrialized Products Tax (IPI) levied on cars with 1,0 liter engines or smaller, creating the carro popular (popular car). The Fiat Uno was the first such car to become a hit, boosting Fiat's growth in the country's auto market. Within a few years, all automakers had followed Fiat's lead and launched their popular models: the GM Corsa and the Volkswagen Gol 1000 are but two examples. This is the main car segment in the country, sometimes having reached up to almost $70 \%$ of the sold units.

Figure 5 shows the evolution of global sales of each of the major automakers in a global context.

Figure 6 shows the growing sales participation of the Brazilian market towards global sales for each of the 10 automakers. When automakers are ranked according to the importance of the Brazilian market to their sales, a complete reversal of rankings can be perceived.

Fiat, which holds ninth place in global sales, depends most on the Brazilian market. More than a quarter of its sales are concentrated in Brazil (26.95\%), versus 17.13\% in 2003 (when Fiat launched its first flex-fuel car in Brazil) and $17.76 \%$ in 1997. According to The Economist (ECONOMIST, 2009, p. 69), over 50\% of the Fiat conglomerate's profits originate in Brazil, which makes it a central country for its global, regional, and local strategies. Fiat entered Brazil in 1976, with the "1050 $\mathrm{cm}^{3}$-engine" Fiat 147. In 1979, it became the first model to be adapted to run on ethanol.

Volkswagen, which places third in 2008 worldwide sales, has the second highest concentration of sales in Brazil: the country accounted for $9.35 \%$ of its global sales in 2008 . In 2003, when Volkswagen launched its first flex-fuel car in Brazil, this figure was $5.81 \%$, compared to $13.55 \%$ in 1997. In 1953, Volkswagen opened its Brazilian branch, and, began to assemble assembled its vehicles, Beetle and Bus. Full-scale manufacturing in Brazil began in 1957 with the "Kombi" (VW Bus). In 1959, the automaker launched the Brazilian version of the Beetle, the "Fusca", with 54\% content nationalization. It was the first to introduce a flex fuel model in 2003.

$\mathrm{GM}$, the second in the 2008 worldwide sales ranking, was the third most dependent on the Brazilian domestic market, with $7.05 \%$ of its sales occurring in the country, versus $4.15 \%$ in 2003 (when it launched its first flex-fuel vehicle) and $4.67 \%$ in 1997. General Motors came to Brazil in 1925. In 1930, GM moved to a 45,000-sq m plant at São Caetano do Sul, São Paulo.

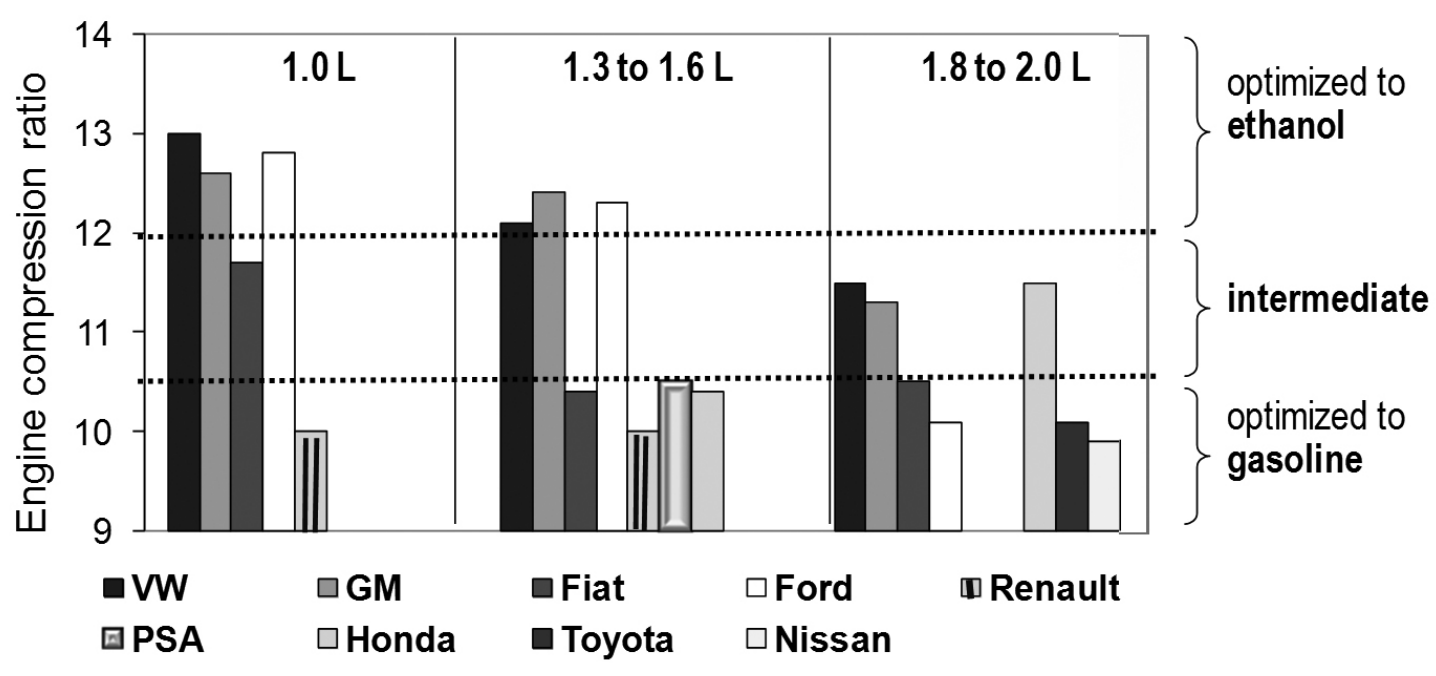

Figura 4. Engine compression ratios of Brazilian flex fuel cars by automakers. Sources: Data collected by authors from technical automotive sites and magazines. 
Ford was the fourth largest automaker worldwide sales ranking and the fourth most dependent on the Brazilian market, with $5.30 \%$ of its 2008 sales occurring in the country, versus $2.89 \%$ in 2004 (when it launched its first flex-fuel vehicle) and $4.01 \%$ in 1997. The Ford Motor Company arrived at São Paulo in 1919. Its first project was the assembly of the famous Model T, and by 1920, it was assembling trucks. Ford launched its first genuinely "Brazilian" truck, the F-600, in 1957, and soon afterwards began production of the F-100, giving birth to the pickup truck segment in Brazil.

PSA/Peugeot-Citroën, which held the eighth position on the international market, has increasingly concentrated its sales in Brazil, up from $0.41 \%$ in 1997 to $2.37 \%$ in 2005 (when it launched its first flex-fuel car in Brazil) and becoming fifth in 2008 , with $5.11 \%$. Peugeot now offers models in the popular segment (less than US\$17,000.00),

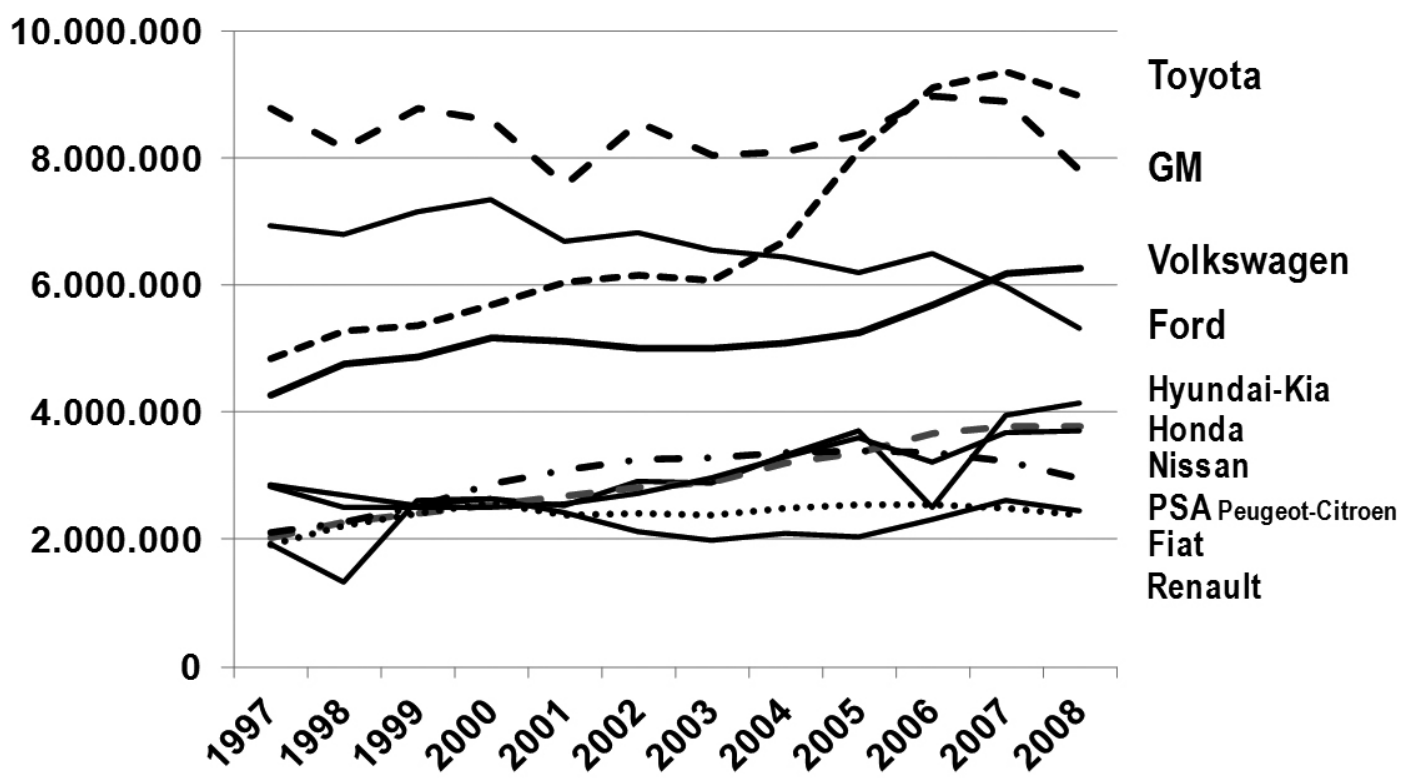

Figura 5. World Sales by Automaker, in units. Source: ANFAVEA (ASSOCIAÇÃO..., 2010) and AUTOINTELL (AUTOMOTIVE..., 2010). Adapted by the authors.

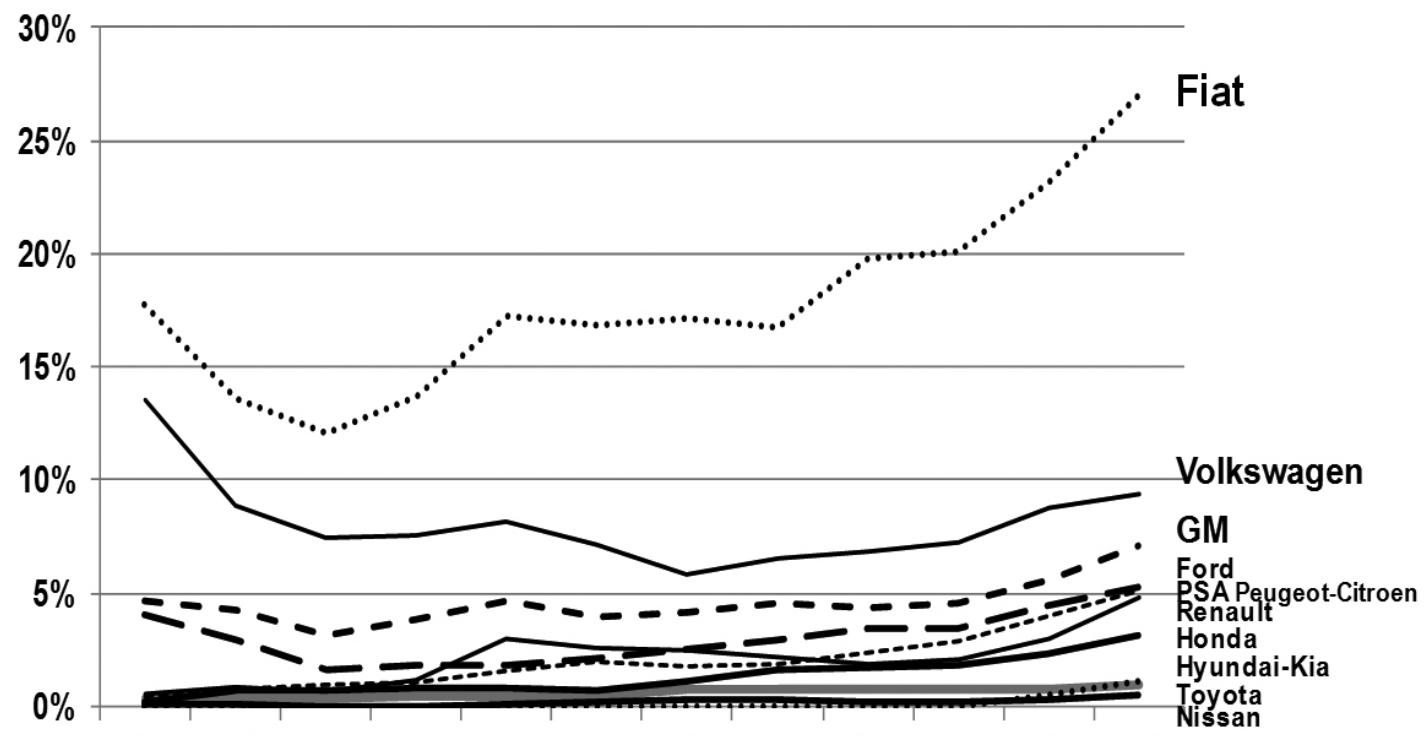

199719981999200020012002200320042005200620072008

Figura 6. Participation of Brazilian Affiliates towards Global Automaker Sales. Source: ANFAVEA (ASSOCIAÇÃO..., 2010) and AUTOINTELL (AUTOMOTIVE..., 2010). Adapted by the authors. 
hurried to launch a flex-fuel vehicle (2005) and is fifth overall in sales in the country.

Renault, which held the tenth spot worldwide, was the sixth automaker most dependent on the Brazilian market: $4.83 \%$ of its 2008 sales occurred in Brazil, up from $2.15 \%$ in 2004 (when it launched its first flex-fuel car in the country) and $0.5 \%$ in 1997 ;

Honda, with the sixth largest worldwide auto sales in 2008, held the seventh spot for reliance on Brazil, with $3.11 \%$ of its global sales occurring in the Brazilian market. It is also long established as the major player in the Brazilian motorcycle market. Honda still does not produce subcompact cars.

Hyundai-Kia Automotive, which placed fifth in global sales in 2008, was the eighth most dependent on Brazilian sales: $1.05 \%$ of its sales are concentrated in the country. By 2011, Hyundai had launched its first flex-fuel car.

Toyota, which held the number-one spot in the worldwide market in 2008, has modest sales in Brazil. In $2008,0.89 \%$ of its sales occurred in Brazil, up slightly from $0.77 \%$ at the time of its first flex-fuel launch in the country, and $0.31 \%$ in 1997 . Toyota had old manufacturing facilities in the country, since the 1950s. However, had thus far specialized in Jeep-like utility vehicles with no models for the subcompact mass market.

Nissan, seventh overall in the 2008 global sales ranking, had been showing constant growth on the Brazilian domestic market, up from $0.04 \%$ in 1997 to $0.47 \%$ in 2008. This steady growth may have pushed for the launch of its first flex-fuel car, in 2009.

Thus, until a decade ago, only four automakers manufactured light vehicles for the mass market in Brazil: Volkswagen, General Motors, Ford, and Fiat. General Motors (GM), Volkswagen (VW) and Ford, as well as Fiat, were operating in Brazil for decades and in 2009 were responsible, together, for $82 \%$ of Brazilian passenger cars production. Whereas Toyota, Daimler, Renault, PSA Peugeot-Citroën, Honda and Nissan have inaugurated their first passenger car plants in Brazil in the late 1990s and therefore can be considered newcomers.

The key point is that automakers in 5th place and below have had a much more recent local industrial history. These automakers only reached for the Brazilian domestic market after the 1990s. Automakers from several countries, such as Audi, Toyota, Honda, Nissan, Volvo, Citroën, Peugeot, and Renault, started to compete with vehicles made in Brazil and eventually began setting up plants in the country, which had thus far been dominated by the local big four (Volkswagen, GM, Fiat, and Ford).

\section{Product development at Brazilian automakers subsidiaries}

Innovation has long been viewed as a central factor in multinational corporations' birth and long-term growth. It is also well established that innovation and R\&D activities are concentrated in the multinational corporation's - MNC - home base. There is a limited amount of activity abroad, also concentrated in a small group of industrialized countries. Ronstad and Kramer (1982) already pointed out ten countries that the United States corporations most favor for R\&D activities: United Kingdom, Germany, France, Canada, Brazil, Japan, Netherlands, Australia, Italy, and Mexico. They also indicated that European companies tended to favor the United States, India, Brazil, Spain, the United Kingdom, Australia, Germany, and Italy. So Brazil looms large in the R\&D decentralization strategies of Western Companies.

Ronstadt (1984, p. 94) also studied the R\&D units' evolution over time, concluding that, regardless of their original purpose, $R \& D$ units tended to change their purpose to "[...] developing new and improved products and processes expressly for particular nations or regional foreign markets." The author also observed "[...] a tendency toward slow growth or divestment if a change of purpose does not occur $[\ldots]$ "...

Cantwell (1995, p. 155) saw a new pattern.

[...] over the last 20 years, technology leaders have been ahead [...] in developing internal international networks to exploit locationally differentiated potential of foreign centers of excellence.

As Nascimento and Plonski (2001) pointed out, this seemed to bring an opportunity for emerging economies to attract foreign controlled R\&D investments, particularly in Brazil.

Investing more than USD 70 billion in research and development (R\&D) in 2008 (4.2\% of revenue), the global automotive industry is among the three largest sectors in R\&D spending. Five out of the top ten global firms ranked by R\&D investment are automakers, as shown in Figure 7 (DEPARTMENT..., 2009) and all of them have industrial operations in Brazil.

The data shows an increasing trend of $R \& D$ investments and corroborate the evaluation of the specialized literature that the automotive industry has been reinforcing the importance of their product development (PD) activities as a strategic factor for competitiveness (CARVALHO, 2008), (CLARK; FUJIMOTO, 1991), as more than $80 \%$ of their total R\&D spending is directly focused on vehicles development programs (CHANARON, 1998).

Distinctly from the concept of world car - a vehicle that could be sold in markets around the world with minor modifications - a trend observed in the 1980's and that has not produced the expected results, currently the global platform strategy is dominant, involving adjustments to specific country requirements. At the same time, the global automakers are striving to share more auto parts among their 


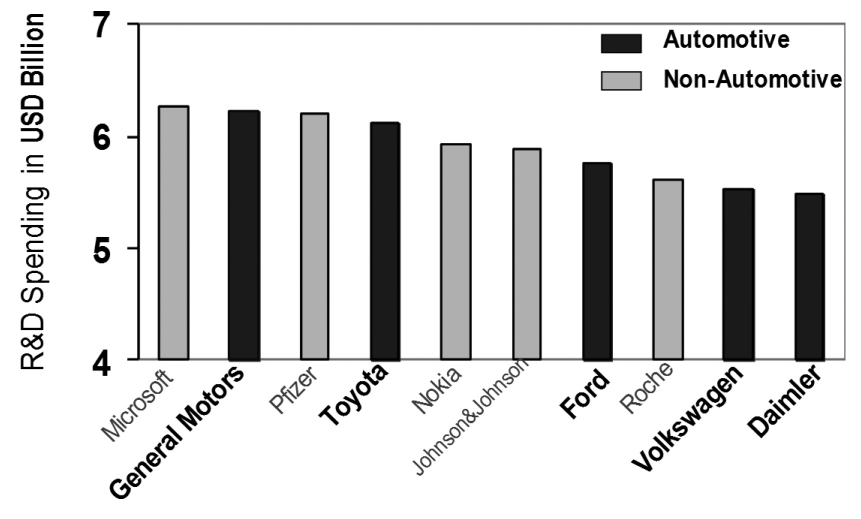

Figure 7. Top 10 Global Companies by 2008 R\&D Spending. Source: The $2008 R \& D$ Scoreboard, DTI (DEPARTAMENT..., 2009).

global vehicle families, therefore increasing economies of scale - a critical aspect of competition in the sector, while keeping products highly differentiated to the end customer.

As a result, the automotive corporations adopt PD structures with some decentralization. So, some dispute is to be expected between subsidiaries and even between them and their headquarters to host more advanced development programs (AMATUCCI; BERNARDES, 2009).

A MIT study (MOAVENZADEH, 2006) reports that GM and Ford (and at some level, Volkswagen) corporations are following a decentralized R\&D model: distributed and (mostly) independent, or distributed but coordinated, regional PD centers. Toyota and Honda are striving toward the same goal, but from the starting point of a highly centralized R\&D model: very little PD activity outside the corporation home country and regional manufacturing with strong reporting to their headquarters. For Consoni and Quadros (2002), Fiat has adopted local PD activities associated with a partly decentralized global strategy, and since the 1990' has focused on emerging markets (CARVALHO, 2005).

Given the theme's significance for the countries hosting MNC's subsidiaries, it is essential to understand the key factors in these global R\&D location trends.

Dias and Salerno (2004) concluded that the greater its importance for the corporation, the more likely it is for the subsidiary to attract and upgrade global R\&D activities. In other words, besides the corporate strategies relating to the $R \& D$ structure (decentralization of $R \& D$ activities, encouraging autonomy and competition among its units), also crucial are other subsidiary attributes, as its trajectory (cumulative technological capabilities, the pattern of subsidiary-parent linkages), financial performance, relevance of the local market, among others.

Consoni and Quadros $(2002,2003,2006)$ emphasize the notable heterogeneity found in the technological trajectories of automotive subsidiaries in Brazil. They have distinct levels of autonomy and complexity in their R\&D activities, specially relating to the differentiated stage of integration of these branches in their corporate strategies. The basic responsibility of all the Brazilian automakers subsidiaries is to conduct $R \& D$ activities relating to the nationalization of parts and components, which involve the processes of evaluation and contracting of local suppliers. Another level, more dynamic and complex, refers to tropicalization, i.e., adapting global platforms and derivative models to specific local market requirements and conditions.

Four Brazilian subsidiaries - VW, GM, Fiat and Ford - have developed a strong basis in such competencies, which has given them a considerable competitive advantage over newcomers. Most of the newcomers have not gone beyond the basic level of nationalization since they have depended on technological activities in their own headquarters, thus following a completely centralized product strategy in Brazil (CONSONI; QUADROS, 2003, 2006). It is important to mention that new comers' scale of operations in Brazil is small and therefore makes it difficult to amortize the investment on local R\&D activities. In general, the newcomers have been concentrating mainly on the consolidation of their manufacturing base and on the integration of their local supply chain (CONSONI; QUADROS, 2006). However, the Brazilian Renault subsidiary is engaged in an active process of consolidation of its engineering capability, seeking favorable conditions to attract more complex PD projects (DIAS; SALERNO, 2004, 2009).

Meeting the specific local demands, the older subsidiaries have achieved large specialization in the design of small engines up to $1,000 \mathrm{cc}$ (1.0 liter of engine displacement), as well as in ethanol engines, flex fuel engines, the adaptation of suspension module to road conditions, the search of low cost solutions, destined mainly to the subcompact (entry level) cars segment.

These accumulated $R \& D$ competencies allowed these subsidiaries to upgrade their activities, taking the responsibility for local models and derivative cars projects. GM, Fiat and VW have adopted decentralized product strategies, although following the global platform concept. In the 1990's, Ford choose to centralize its technological activities in its European and USA R\&D centers, but such strategy has left the company in a fragile position in the local market. Recently, Ford decided to invest again in their $R \& D$ capabilities in Brazil.

In the last few years, partial derivative projects (concept and design) have been performed under Brazilian engineering team coordination in VW (Polo Sedan / Polo platform), GM (Montana Pick-up/ Corsa platform), Fiat (Siena/ Palio platform) and Ford (Fiesta Sedan/ Fiesta platform). However, both Fiat and Ford have not yet gone 
beyond this level. Only VW and GM subsidiaries have reached the level of designing and engineering entirely new models from existing platforms with the development of the Fox and the Meriva models, respectively. Such completely new derivatives are global products developed in Brazil for South American and European markets (CONSONI; QUADROS, 2006).

Fiat recently announced that its subsidiary in Brazil would assume the mandate for the complete development of vehicles to local/regional market. The opportunities to demonstrate technological capabilities for designing a complete platform, particularly for the compact and low cost segments, suggest the possibility that they are becoming partners to their headquarters in global products development. It should be noted that the PD management in emerging markets is influenced not only by the global competitive strategies regarding products, production, investments and $\mathrm{R} \& \mathrm{D}$, but also by interaction with government policies and availability of skilled human resources in the subsidiary host country, among other factors (CONSONI; QUADROS, 2003).

Von Zedtwitz and Gassmann (2002) corroborate that, concluding that access and support to local markets, and access to local science and technology mainly influence the establishment of new R\&D units. The technical and marketing maturity of the Brazilian subsidiaries of automakers such as VW and GM, both of which have advanced R\&D centers in Brazil, help explain their leading role in the introduction of ethanol and, later on, flex-fuel engines (YU et al., 2009a). The same seems to be true regarding the development of electronic fuel injection systems by tier 1 auto parts suppliers - Bosch and Magneti Marelli (YU et al., 2009b).

Analysis of the competitive global strategies of the multinational automotive assemblers, with operations in Brazil, show that in general there is an expressive correlation among those strategies, their local R\&D structure, and the technological trajectories of their Brazilian subsidiaries (CARVALHO, 2005).

The global automakers with a long standing industrial presence in Brazil have adopted decentralized R\&D structure - VW, GM, Fiat and Ford - and show expressive local R\&D capabilities, stronger development of specific derivative products or platforms to local and / or emerging markets, launching of models markedly adapted to Brazilian characteristics and tastes (subcompact flex fuel cars), and therefore have better performance in passenger cars market share in Brazil.

In 1980, VW was the first Brazilian subsidiary to offer subcompact models designed and developed by a local $R \& D$ center. The so called Gol Family is currently in its $5^{\text {th }}$ generation, and, not coincidentally, the first VW flex-fuel car came from this product line. Long after its inception, the basic Gol car was a bestselling model, and still runs deep in consumer preferences. VW has also maintained a continuous effort to adapt and improve ethanol engines and essential power train subsystems, effectively ensuring a leadership position in ethanol and flex-fuel technology.

The Fiat subsidiary in Brazil, already a global reference in alternative fuel in Fiat group, has assumed the mandate for the complete development of vehicles to the local market, increasing its participation in global projects. The Brazilian GM unit has recently developed a tri-fuel model (ethanol-gasoline-natural gas) (SAE..., 2009). As have its competitors, the Ford subsidiary has made considerable effort to offer cars that run on an ethanol and gasoline blend as well as on hydrate ethanol, and was thus in a favorable position to respond quickly to the flex-fuel challenge.

On the other hand, Toyota, the largest carmaker worldwide in 2008 (INTERNATIONAL..., 2010), has only a modest market share in Brazil - 2.2\% of 2009 sales in passenger cars segment (ASSOCIAÇÃO..., 2010), due mainly to the absence in its product portfolio of subcompact car.

\section{Conclusions}

Brazil had a strong and old sugarcane industry and strong government regulation over and incentives to ethanol production and use in light vehicles.

The Brazilian auto industry is made of MNC subsidiaries. Fiat, GM, Volkswagen and Ford are the largest and have a long industrial history in the country. Toyota and Honda also have a long local industrial tradition. But until very recently, they were out of the main markets. All other subsidiaries are relatively small and have a much shorter Brazilian industrial history.

GM and Volkswagen also have a long R\&D history in Brazil, followed by Ford and Fiat. They have whole car families customized for Brazil. These companies have developed models for the Brazilian market, and, on occasion, even whole new ones.

Fiat, GM, VW, and Ford have been deeply involved with ethanol since the 80's. They first adapted power trains to run on gasohol, and fast followed through to pure hydrate ethanol (around 5\% water), improving their engines performances ever since.

It is no surprise then that VW, GM, Fiat and Ford subsidiaries were the first automakers to develop flex-fuel cars, after the 1990s ethanol shortage. In fact, the question should perhaps be the opposite: why did it took them nearly 15 years to react? Perhaps there was some reluctance on their headquarters.

It is also easy to explain the differences in affiliates' strategy concerning ethanol. Clearly, automakers with a large stake in the country went first. Here the dominance 
of the Brazilian market by subcompact (entry level) cars also played a role. Subcompact cars, manufactured in large numbers for the emerging mass market, were almost the exclusive province of the four main market players.

The lagging behavior of Toyota and Honda subsidiaries, also long standing auto producers in Brazil, may be explained by their target markets and smaller role in their companies. First, they targeted utility vehicles and motorcycles. Then, they entered the high-end market with imported vehicles. Only then, they did start producing vehicles in the country, and they still are off the main market, the subcompact segment. No wonder, then, that despite their being long established, it took them some time to react and then their choice of a very conservative technological approach. Honda, however, seems to be coming around now.

All this suggests that Porter's diamond really need to be seen through a subsidiaries and local point of view, as pointed out by Moon, Rugman and Verbeke (1998). Moreover, subsidiaries may have a strategic role and pioneer emergent strategies, but this is conditioned by their R\&D capability and importance to their mother company, which correlates with their autonomy, as well as to institutional factors, like international market size and characteristics significance, production factors markets, and government policies.

\section{References}

AGÊNCIA NACIONAL DO PETRÓLEO - ANP. Brasil. Available from: $<\mathrm{http}: / / \mathrm{www}$.anp.gov.br/?id=470>. Access in: 28 July 2011, 10:06.

AMATUCCI, M.; BERNARDES, R. C. Building competencies for product development in Brazilian subsidiaries of the automotive industry. Produção, v. 19, n. 2, p. 359-375, 2009.

AMATUCCI, M.; SPERS, E. E. The Brazilian biofuel: your wallet or your life. In: ENCONTRO DA ASSOCIAÇÃODOS PROGRAMAS DE PÓS-GRADUAÇÃO E PESQUISA EM ADMINISTRAÇÃO, 33., 2009. Anais... São Paulo: ANPAD, 2009. p. 19-23.

ANDREWS, K. R. The Concept of Corporate Strategy. In: MINTZBERG, H.; QUINN, J. B. (Eds.). The Strategy Process - Concepts, Contexts, Cases. 2nd ed. New Jersey: Prentice Hall, Englewood Cliffs, 1991.

ANSOFF, H. I. The New Corporate Strategy. New York: John Wiley \& Sons, 1988.

ASSOCIAÇÃO NACIONAL DOS FABRICANTES DE VEÍCULOS AUTOMOTORES - ANFAVEA. 2010. Available from: <http://www.anfavea.com.br>. Access in: 21 Jan. 2010.

AUTOMOTIVE INTELLIGENCE - AUTOINTELL. 2010. Available from: <http://www.autointell.com>. Access in: 21 Jan. 2010.

BARROS, A. Brasil ganha três posições e é o sexto maior mercado em 2008. 2009. Available from: <http://www. autodata.com.br/news.php?recid=10351>. Acesso em: 12 nov. 2009.

BOWER, J. L.; DOZ, Y. L.; GILBERT, C. G. Linking Resource Allocation to Strategy. In: BOWER, J. L.; GILBERT, C. G. (Eds.). From Resource Allocation to Strategy. Oxford: Oxford University Press, 2005.

CANTWELL, J. The Globalization of Technology: What Remains of The Product Cycle Model. Cambridge Journal of Economics, v. 19, p. 155-174, 1995.

CARVALHO, E. G. Globalization and competitive strategies in the automotive industry: an approach from the perspective of the main assemblers in Brazil. Gestão \& Produção, v. 12, n. 1, p. 121-133, 2005.

CARVALHO, E. G. Technological innovation in the automotive industry: features and recent evolution. Economia e Sociedade, v. 17, n. 3, p. 429-461, 2008.

CHANARON, J. J. Automobiles: a static technology, a 'waitand-see' industry? Technology Management, v. 16, n. 7. p. 595-630, 1998.

CLARK, K. B.; FUJIMOTO. T, Product Development Performance: Strategy, Organization, and Management in The World/auto Industry. Boston: Harvard Business School, 1991.

CONSONI, F.; QUADROS, R. Desenvolvimento de produtos na indústria automobilística brasileira: perspectivas e obstáculos para a capacitação local. Revista de Administração Contemporânea, v. 6, n. 1, p. 39-62, 2002. http://dx.doi.org/10.1590/S1415-65552002000100004

CONSONI, F.; QUADROS, R. Between centralization and decentralization of product development competencies: recent trajectory changes in Brazilian subsidiaries of car assemblers. In: INTERNATIONAL COLLOQUIUM OF GERPISA, 11., 2003, Paris. Proceedings.... Paris: Ministère de la Recherche, 2003, p. 15.

CONSONI, F.; QUADROS, R. From adaptation to complete vehicle design: a case study of product development capabilities in a carmaker in Brazil. International Journal of Technological Management, v. 36, n. 1-3, p. 91107, 2006. http://dx.doi.org/10.1504/IJTM.2006.009963

DIAS, A. V. C.; SALERNO, M. S. International division of labour in product development activities: towards a selective decentralization? International Journal of Automotive Technology and Management, v. 4, n. 2-3, p. 223-239, 2004. http://dx.doi.org/10.1504/ IJATM.2004.005327

DIAS, A. V. C.; SALERNO, M. S. Decentralization of Research, Development and Engineering activities in transnational corporations: contributions to theory from a subsidiary perspective. Gestão \& Produção, v. 16, n. 2, p. 187-199, 2009. 
DEPARTMENT OF TRADE AND INDUSTRY - DTI. The 2008 R\&D Scoreboard: the top 750 UK and 1400 global companies by R\&D investments. DTI, 2009.

ECONOMIST. London: Economist Newspaper Limited, 1928-. n. Jan 17-23, p. 69, 2009

GOLDENBERG, J. et al. Ethanol learning curve - the Brazilian experience. Biomass and Bioenergy, v. 26, p. 301-4, 2004. http://dx.doi.org/10.1016/S0961-9534(03)00125-9

INTERNATIONAL ORGANIZATION OF MOTOR VEHICLE MANUFACTURERS - OICA. 2010. World Ranking of Motor Vehicle Manufacturers. Available from: <www.oica.net>. Access in: 21 Jan 2010.

JATO DYNAMICS. Jato do Brasil Informações Automotivas Ltda. Semestral Fenabrave, 2009.

KOGUT, B.; ZANDER, U. Knowledge of the Firm and the Evolutionary Theory of the Multinational Corporation. Journal of International Business Studies, v. 24, n. 4, p. 625-45, 1993. http://dx.doi.org/10.1057/palgrave. jibs.8490248

LONDON, J.; HART, S. S. Reinventing Strategies for Emerging Markets: Beyond The Transnational Model. Journal of International Business Studies, v. 35, p. 350-70, 2004. http://dx.doi.org/10.1057/palgrave.jibs.8400099

MACEDO, I. Situação atual e perspectivas do etanol. Estudos Avançados, v. 21, n. 59, p. 157-65, 2007. http://dx.doi. org/10.1590/S0103-40142007000100012

MARQUES, J. J. O “Plástico Verde” e o Mercado Brasileiro de Etanol. 2011. Thesis (Doctorate)-University of São Paulo, São Paulo, 2011.

MINTZBERG, H. Patterns in Strategy Formation. Management Science, v. 24, n. 9, p. 934-48, 1978. http://dx.doi. org/10.1287/mnsc.24.9.934

MINTZBERG, H. Five P's for Strategy. In: MINTZBERG, H.; QUINN, J. B. The Strategy Process: Concepts, Contexts and Cases. Englewood Cliffs: Prentice Hall, 1991.

MOAVENZADEH, J. Offshoring automotive engineering: globalization and footprint strategy in the motor vehicle industry. MIT International Motor Vehicle Program Report. In: NEA WORKSHOP ON OFFSHORING OF ENGINEERING, 2006, Washington. Proceedings... Washington: SEFI, 2006.

MOON, H. C.; RUGMAN, A. M.; VERBEKE, A. A generalized double diamond approach to the global competitiveness of Korea and Singapore. International Business Review, v. 7, p. 135-50, 1998. http://dx.doi.org/10.1016/S09695931(98)00002-X

NARDON, L.; ATEN, K. Beyond a better mousetrap: A cultural analysis of the adoption of ethanol in Brazil. Journal of World Business, v. 43, p. 261-73, 2008. http://dx.doi. org/10.1016/j.jwb.2008.03.008
NASCIMENTO, P. T. S.; PLONSKI, G. A. Global Management of Technology: A Perspective From Brazil. In: BALAS ANNUAL CONFERENCE, 2001, San Diego. Proceedings... San Diego: University of San Diego, 2001, p. 4-7.

NASCIMENTO, P. T. et al. Competência compartilhada na determinação da trajetória tecnológica do sistema flex-fuel: o caso Delphi. In: SEMINARIO LATINO-IBEROAMERICANO DE GESTIÓN TECNOLÓGICA, 12., 2009, Cartagena. Anais... Cartagena: ALTEC, 2009a.

NASCIMENTO, P. T. et al. Exogenous factors in the development of flex fuel cars as a local dominant technology. Journal of Technology Management \& Innovation, v. 4, n. 4, p. 110-19, 2009b.

NIGRO, F.; SZWARC, A. Etanol como Combustível Veicular: Perspectivas Tecnológicas e Propostas de Políticas Públicas. São Paulo: ÚNICA, SP, 2008.

NODA, T.; BOWER, J. L. Strategy Making as an Iterated Process of Resource Allocation. In: BOWER, J. L.; GILBERT, C. G. (Ed.). From Resource Allocation to Strategy. New York: Oxford University Press, 2005.

PEFlEY, R. K.; PUllMAN, J. B.; SUGE, T. P.; E ESPINOLA, S. A feedback controlled fuel injection system can accommodate any alcohol-gasoline blend. In: PROCEEDINGS OF THE IV INTERNATIONAL SYMPOSIUM ON ALCOHOL FUELS TECHNOLOGY, I., 1980, Guaruja. Proceedings... 1980. 1980. p 247-253.

PORTER, M. E. The Competitive Advantage of Nations. Harvard Business Review, Mar/Apr, 1990.

RONSTADT, R. R.; ABROAD, D. US MNCs: The Choice, Transfer and Management of International Technology Flows. In: STOBAUGH, R.; WELLS JUNIOR,, L. T. (Eds.). Technology crossing borders. Boston: Harvard Business School Press, 1984. p. 94.

RONSTADT, R., KRAMER, R. J. Getting the Most Out of Innovation Abroad. Harvard Business Review, p. 94-99, 1982.

SAE BRASIL - Engenharia Automotiva. Novo patamar para a Fiat, v. 9, n. 37, p. 10, 2009.

YU, A. S. O. et al. The evolution of flex-fuel technology in Brazil: The Bosch case. In: PORTLAND INTERNATIONAL CONFERENCE ON MANAGEMENT OF ENGINEERING AND TECHNOLOGY, 2009, Portland. Proceedings... Portland: PICMET, 2009a.

YU, A. S. O. et al. Supplier involvement in flex-fuel technology development: The General Motors and Volkswagen Brazilian cases. In: PORTLAND INTERNATIONAL CONFERENCE ON MANAGEMENT OF ENGINEERING AND TECHNOLOGY, 2009, Portland. Proceedings... Portland: PICMET, 2009b. 
YU, A. S. O.; NASCIMENTO, P. T.; SILVA, L. L. C.;

CAMARGO JR., A. S.; DURANTI, C. M.; E MOURA, C. B. Evolution of Flex Fuel Technology: a Case Study. In: VOLKSWAGEN BRASIL, 34., 2010, Rio de Janeiro, Proceedings... ENANPAD, 2010.
VON ZEDTWITZ, M.; GASSMANN, O. Market versus technology drive in R\&D internationalization: four different patterns of managing research and development. Research Policy, v. 31, n. 4, p. 569-88, 2002. http://dx.doi. org/10.1016/S0048-7333(01)00125-1 